ETHICS OF FILMMAKER-SUBJECT RELATIONSHIPS IN DOCUMENTARY

A Thesis
presented to
the Faculty of the Graduate School
at the University of Missouri-Columbia
In Partial Fulfillment
of the Requirements for the Degree
Master of Arts
Dr. Tim P. Vos, Thesis Supervisor

AUGUST, 2014 
The undersigned, appointed by the dean of the Graduate School, have examined the thesis entitled

\section{ETHICS OF FILMMAKER-SUBJECT RELATIONSHIPS IN DOCUMENTARY FILMS}

presented by Olga Khrustaleva,

a candidate for the degree of Master of the Arts in Journalism

and hereby certify that, in their opinion, it is worthy of acceptance.

Professor Tim Vos

Professor Steve Rice

Professor Amy McCombs

Professor Bradley Prager 


\section{DEDICATION}

Thanks to my family who I have seen just once since I came to Columbia two years ago. You who has always been supportive of all my academic and professional endeavors, even the most crazy ones, and I can't express how much I appreciate your help and encouragement.

Thanks to my friends in Columbia, MO who have become my family here and have always been there for me. Without you these two years would not have been as exciting and enriching as they were. 


\section{ACKNOWLEDGEMENTS}

First, thanks to documentary filmmakers who agreed to be part of this research project. Without your vast knowledge, experience and willingness to share both, this project would not have been possible, and I hope, if you will read it, you will find it as interesting as I did when writing it.

Thanks to the School of Journalism faculty, who have always helped me throughout my two years here. I have a deep respect for you all.

Thanks to the Fulbright scholarship fund for giving me this amazing opportunity to be part of one of the best journalism schools in the world. 


\title{
ETHICS OF FILMMAKER-SUBJECT RELATIONSHIPS IN DOCUMENTARY
}

FILMS

\author{
Olga Khrustaleva
}

\section{Dr. Tim Vos, Dissertation Supervisor}

\begin{abstract}
The relationship between filmmaker and subjects is one of the central issues in scholarly research of the documentary genre. It raises many ethical questions - is it possible to document the reality without intervening, and without expressing a certain viewpoint? Does establishing friendly relationships benefit the story or not? Are filmmakers exploiting people by documenting their lives? How truthful are stories of people in a documentary if only a small percentage of footage is used in the final film? Through semi-structured interviews with six prominent independent documentary filmmakers, this study examined filmmakers' relationships with their subjects, and how these relationships influenced ethical decision-making. The study also explored gatekeeping forces affecting the decision-making processes. After the analysis of the interviews the following phenomena emerged as primary findings. Filmmakers choose to have friendly relationships with their subjects, and in critical situations they would intervene and help the subjects versus observing or recording. Committed to telling truthful stories documentarians face the conflict between ethics and aesthetics. Acknowledging some similarities with journalism, filmmakers do not consider what they do journalism. The biggest responsibility filmmakers admit to is a responsibility to their subjects.
\end{abstract}




\section{TABLE OF CONTENS}

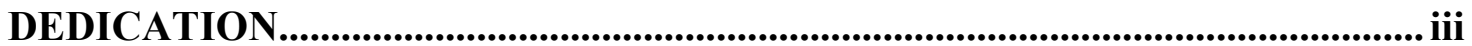

ACKNOWLEDGEMENTS ........................................................................................... iv

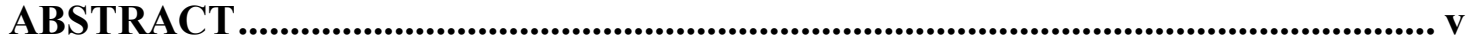

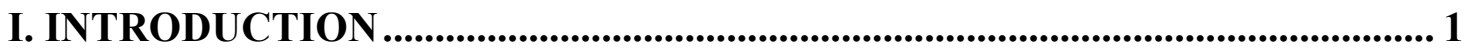

II. LITERATURE REVIEW ............................................................................................... 4

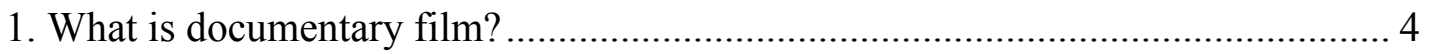

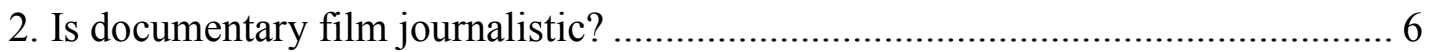

3. Ethics of documentary filmmaking.............................................................. 9

4. Filmmakers as gatekeepers .......................................................................... 13

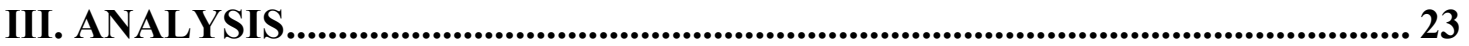

1. Ethical challenges reported by filmmakers during filming and editing process... 23

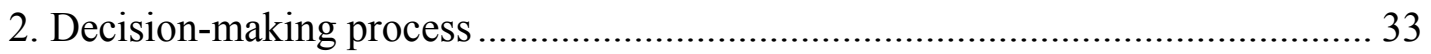

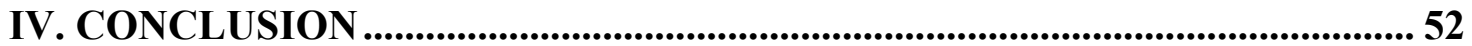

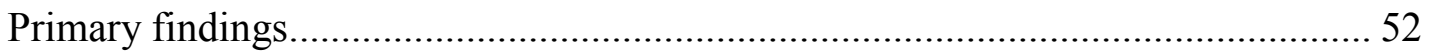

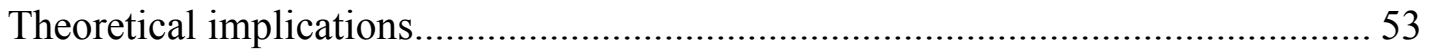

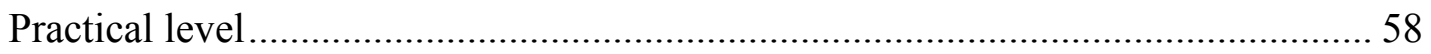

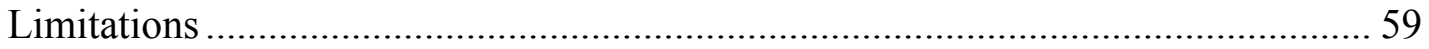

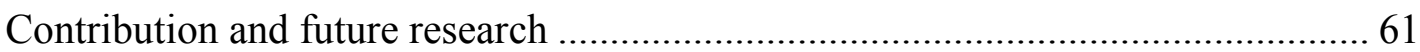

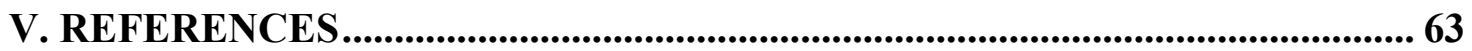




\section{INTRODUCTION}

In his documentary The Revisionaries, Scott Thurman explored the tension between teaching science and creationism in Texas schools and the attempts by the State Board of education to amend school textbooks and include information about creationism. The main subject of the film was Don McLeroy: a dentist, the chairman of the Board of Education and a Sunday school teacher. As a devoted Catholic, McLeroy was a keen supporter of creationism and was working hard to make sure creationist ideas make their way into science textbooks. Some scientists, teachers and parents opposed the idea and the community was divided over the issue. The film shows both sides via interviews and footage from Board of Education meetings. McLeroy says that he believes God created the universe, and he mocks scientists.

The Revisionaries was shown at the Ragtag Movie Theater in Columbia, MO on October 2, 2012 followed by a question and answer session with Thurman. Some asked what McLeroy thought of the film, because general audiences found that he was portrayed as an unintelligent, stubborn man with ridiculous views. Thurman said that he is often asked this question, and that McLeroy actually liked the movie a lot because it was true and presented his views accurately. Thurman added that the organizers of the Tribeca Film Festival invited McLeroy to the festival and that a New York audience looked at him as "some sort of a living dinosaur". Thurman wrote on the film's website ${ }^{1}$

\footnotetext{
1 The Revisionaries, official website. http://www.therevisionariesmovie.com/about.html
} 
As I continued to seek intimate access to a few people that were heavily involved, I was drawn to the magnetic personality of Don McLeroy... After a year of efforts to gain access, Don slowly opened up to me, eventually allowing me full access to his personal life at work, in his fourth grade Sunday school class and in his home.

It was not Thurman's intention to favor either side of the argument or portray one side as ridiculous. He was "representing reality" (Nichols, 1992) and the fact that McLeroy actually liked the film shows that Thurman succeeded in constructing a balanced story.

The relationship between filmmaker and subjects is one of the central issues in scholarly research of the documentary genre (Grierson, 1933; Nichols, 2006; Renov, 1993; Pryluck, 1976). It raises many ethical questions. Is it possible to document the reality without intervening, and without expressing a certain viewpoint? Should filmmakers treat people they are filming as subjects, or like "original (native) actors" (Grierson, 1933)? Are filmmakers exploiting people by documenting their lives? How truthful are stories of people in a documentary if only a small percent of footage is used in the final film? What gatekeeping forces are affecting filmmaking process?

This qualitative study used in-depth semi-structured interviews with filmmakers to explore the filmmaker-subject relationship in documentary film, and understand what influences filmmakers' ethical decision-making. On a theoretical level this research would contribute to the studies that lie on the border between documentary filmmaking and journalism. On the practical level the empirical data collected in this research can be used to develop guidelines for documentary filmmakers that would address ethical issues concerning the filmmaker-subject relationship. 


\section{LITERATURE REVIEW}

This literature review study addresses the issue of the filmmaker-subject relationship in documentary film and the ethical questions it raises. One of these questions is how much filmmakers are intervening and crafting the stories of their subjects. The second key question that scholars have been discussing is the whether or not there should be a code of ethics for documentary filmmakers, which would introduce some clarity into the filmmaking process.

\section{What is documentary film?}

There have been attempts to define documentary film since its genesis as a genre in the beginning of the $20^{\text {th }}$ century. At that time, when cinema in general was only emerging, documentary film was treated as a form or art. One of the first attempts to explain documentary film was made in John Grierson's book 'First Principles of Documentary' (Grierson, 1933) in which he developed three main principles of documentary and reasons why it "has [a] big future" as a genre of cinema.

One of Grierson's main points is that cinema has the "capacity for getting around, for observing and selecting from life itself, [and] can be exploited in a new and vital art form." He says that documentary captures "the living scene and the living story" (p. 8). Are documentary filmmakers and journalists just observing reality or does the presence of the camera, or even a stranger with a notebook, alter the reality that they are supposedly observing? 
The second issue Grierson addresses is found in the relationships with subjects or subjects, who Grierson refers to as 'actors'. He believes that "the original (or native) actor, and the original (or native) scene, are better guides to a screen interpretation of the modern world" because they give a more multifaceted interpretation of reality. The philosophical question here is how much reality there is left in documentary film. In actuality it is reality seen through a double prism - first through the prism of subjects, and then through the prism of a filmmaker.

The third thing he writes about is "spontaneous gesture" which can bring a "special value for the screen." Grierson says that documentaries or "stories from the raw", as he refers to it, can achieve "intimacy of knowledge" (p. 8) and thus can be more effective than the acted story. Grierson's principles emphasize the fact that the sense of reality and truth is greater in documentaries compared to fiction films, which in the $1930 \mathrm{~s}$ focused more on fantastical and adventurous narratives.

Nichols (2010) said that documentary film might have never had a precise definition. He argues though that it "has become the flagship for a cinema of social engagement and distinctive vision" (p. 31). Nichols writes about four modes of representation in documentary film: expository, observational, interactive and reflexive (Nichols, 1992).

The observational mode of documentary allowed filmmakers to capture people's lives without addressing the camera directly. According to Nichols it arose out of "dissatisfaction with the moralizing quality of expository documentary" (1992, p. 33). Observational documentaries, however, required detachment and limited the presence of the filmmaker. The interactive mode of documentary allowed filmmakers to "engage with 
individuals more directly while not reverting to classic exposition" (p. 33). Using archival footage and interviews with witnesses and experts, filmmakers were able to create a more objective picture while at the same time participate more in the process. The reflexive mode of documentary, according to Nichols, "challenges the impression of reality" (p. 33) and, unlike the other three categories, creates a different effect by drawing the viewer's attention to the effect produced rather than to the reality itself.

\section{Is documentary film journalistic?}

Observational and interactive documentaries from Nichols' classification seem to be the more 'journalistic' in a sense than expository and reflexive, though they also do not completely renounce the presence of the filmmaker.

Similar to documentary, the term journalism also lacks a universal definition. The nature of journalism, whether it is a profession, a craft, or something else, has been actively discussed by scholars (Kovach \& Rosenstiel, 2007; Scott, 2005; Davis, 2010; Singer, 2010), especially in connection with the development of the web. Are bloggers journalists? And likewise, can people who publish videos online be considered documentarians?

Craft and Davis (2012) define journalism as "a set of transparent, independent procedures aimed at gathering, verifying and reporting truthful information of consequence to citizens in a democracy" (p. 55). Both documentary and journalism are committed to truth telling, even though journalism has different obligations to citizens and a different role in a democracy. Aufderheide (2012) writes, "[the] documentary genre in film makes distinctive claims to honesty and truth" (p. 362). 
Barnouw (1993) writes that a documentary film itself cannot be considered "the truth" but instead the evidence or the testimony of a fact, a situation of historical process. He categorizes not documentary films, but filmmakers. According to Barnouw a filmmaker can be an explorer, reporter, painter, advocate, bugler, prosecutor, poet, chronicler, promoter, observer, catalyst, and guerilla depending on his or her role in the filmmaking process and the topic of the documentary.

Renov (2004) suggests that documentary film is an important tool for a filmmaker to explore selfhood, so a filmmaker is always present in his or her work. Renov (1993) also writes that documentaries can contain some elements of fiction film. The narrator's voice, musical accompaniment, animation, reenactment, use of close-ups, color correction and other elements all speak for documentary film being more of an art form than journalism.

LaMarre and Landreville (2009) conducted research comparing the different effects on the audience between a PBS documentary film, The Triumph of Evil, and the historical reenactment fictional film Hotel Rwanda. Both films addressed the same issue - 1994 genocide in Rwanda.

Their study showed that "the documentary group reported higher levels of affect, as well as increased issue concern and learning" (p. 550). Based on their qualitative research LaMarre and Landreville came to the conclusion "that socio-political documentaries can play a vital role in both informing and engaging the electorate", and "as a form of political information, have the potential to strongly influence public opinion" (p. 550). The results of the study suggest that, similar to journalism, documentary film affects the audience and informs people about current issues. 
One of the functions of journalism, along with truth telling and verification, is generating social empathy (Kovach \& Rosenstiel, 2007). Representation, or giving voice to the most unprivileged, is also one of the core functions. These are functions often fulfilled by documentary filmmakers as well.

Aufderheide (1998) gives another example, the film A Healthy Baby Girl by Judith Helfand. The film is a video diary of the filmmaker's life after she was diagnosed with cervical cancer as a consequence of her mother taking diethylstilbestrol, a drug that was marketed to prevent miscarriages. Aufderheide writes: "the raw intimacy of the journal format, then, becomes a very public rebuke of the drug manufacturers, whose cold calculations, the video charges, have wrecked the lives not only of the victims but of their families" (1998).

However, in social and political documentaries the line between documenting reality and advocating for specific interpretation of reality is very vague. Michael Moore's Fahrenheit 9/11 has been widely criticized (Nolley, 2005; Rhoads, 2004) for quoting interviewees out of context and carving a storyline which was not exactly true, but rather what the filmmaker believed was true. Being a craftsman of a story, a documentary filmmaker has no legal obligations to be objective. It's usually not advocating for a certain issue or a filmmaker's opinion that causes criticism, but the means. Manipulating the footage too much, flipping quotes and shots to make a point instead of telling the story in context is generally not accepted by most documentarians.

Krawitz (2010), stresses the importance of ethics for novice students of film by highlighting struggles in the industry with respect to ethics. She believes that filmmakers should begin the production process with respect not only for their equipment, but also 
for their audiences and subjects. Continuing in this vein, she chastises the practices of filmmakers like Michael Moore as being deceitful because they use interviews and quotes out of context, using their subjects to fit a certain idea or prove a point.

\section{Ethics of documentary filmmaking}

There are numerous definitions of ethics, which vary depending on which ethical theory is applied. Aristotelian ethics, or virtue ethics, focuses on the inner qualities of a person (or in this context, a filmmaker) that determine the way he or she deals with ethical dilemmas. From the Kantian perspective, an honest and truthful process is the most important. Consequentialism theory emphasizes the final product (film) and from this perspective some ethical compromises can be justified if the final product benefits the audience.

The more recent theories of ethics include libertarian theory, which emphasizes the role of markets and economy in the media, and social responsibility theory, which argues that audience is a key factor in ethical decision-making process because journalists' main goal is to inform the citizens (Siebert, Peterson, \& Schramm, 1963).

When ethics is applied to documentary film, it often incites discussion of ethical codes. Nichols (2006) writes that an ethical code for the documentary filmmaking process would allow the filmmakers to address the "imbalance of power that often arises between filmmakers and both their subjects and their audience" (2006, link).

Maccarone (2010) says that documentary film should be considered a "practice of a social institution" (p. 193) because it involves human interaction. She has no doubt that documentary filmmakers have ethical responsibilities to the 'subjects' of their films because the information that they access comes directly from the subjects. On the other 
hand, filmmakers have obligations to art. However, Maccarone believes that in documentary film "the practices of art and human interaction overlap rather than being differentiated" (p. 202).

While the journalism profession has the SPJ code of ethics, which is not legally enforceable, but is a generally accepted guideline in the industry, there is nothing similar for documentary filmmaking. Independent filmmakers often resist this idea in the case of documentaries broadcasted on TV channels in which journalistic standards may apply. Pryluck (1973) suggests that when ethics is applied to documentary film it is not about morality, but more about aesthetics. "Ethical assumptions have aesthetic consequences, and aesthetic assumptions have ethical consequences" (p. 22). Ethics and aesthetics intertwine in documentary film and both should be taken into consideration in the discussions of the filmmaker's decision-making process and obligations.

Lambeth (1986) suggests that we look at ethics theories as "windows onto the world of moral reasoning", not "gimmicks that can be called upon to accept ethical questions and split forth answers..." (p. 21). It would be hardly possible to come up with a set of universal rules for dealing with ethical dilemmas. However, the combined empirical knowledge that documentary filmmakers acquired in the process would be helpful in creating some guidelines or tips.

Plaisance sets ethics apart from morality by saying that ethical decision-making should be based on "rational justification" (p. 5). Plaisance defines ethics as a "form of inquiry concerned with the process of finding rational justifications of our actions when the values that we hold come into conflict" (p. 6). 
However the concept of "rational justification" creates some vagueness. Patterson and Wilkins argued that "ethics begins where elements of a moral system conflict" (1998, p. 2). Both the terms "moral systems" and "rational justification" create ambiguity as they often vary from country to country or journalist to journalist because some things that are considered the norm in some countries are considered deviant in others. Several media ethics theorists, including Christians and Carey (1989), argued that modern Western ethics theories are largely based on "individual freedom" rather than "universal truths and community welfare" (Plaisance, 2008). This difference in approach to ethics can create difficulties in defining rational justification - it would largely depend on the cultural, political and social background of a filmmaker.

Some documentary filmmakers believe that they are crafting stories rather than documenting events (Aufderheide 2012). "Rather they expect to immerse a viewer in experience that helps explain a reality that previously would have been invisible, opaque, or misunderstood" (p. 366). They spend months and sometimes years to tell one story in order to get in-depth information, understand the context, and get as much detail as possible. In doing so, documentarians often face the challenges of building relationships with their subjects.

Aufderheide interviewed 45 documentarians on the subject of ethical challenges and constraints. Filmmakers reported three levels of relationships while making a film with subjects, with viewers, and with directors of the project (2012). Speaking about subjects, many documentarians said they try to establish "human relationships" but a line remains which should never be crossed. One filmmaker gave an example of having a romantic relationship with a subject as inappropriate. However, they say the rules are still 
different from journalism. "I am in their life for a whole year. So there is a more profound relationship, not a journalistic two or three hours", one documentarian said (p. 369). Being present in someone's life for such an extended period must affect a documentarians' decision-making process.

Sanders (2010) writes about documentary film from the perspective of deontological reasoning. He distinguishes between the process of documentary filmmaking and documentary film, focusing on the former because it is a process that involves decision-making and dealing with ethical constraints, which usually, but not always, result in the final product - documentary film. The process itself is similar to journalism, which results in a published or broadcasted story.

Sanders gives a few examples illustrating that the final product does not always reflect the process. In some cases filmmakers used fake titles for the films and used the interviews to fit the narration, altering the meaning of what their subjects actually said. He says that ethics in documentary filmmaking "is not about judging individual actions or describing what is the right thing to do in a given situation", but "about the principles that inform deliberations and decisions about the right thing to do as a documentary filmmaker" (p.531) to fulfill the responsibilities towards the others and himself. The means and constraints are stricter in journalism, where a professional and his or her work can be denounced if the process involved deception or manipulation.

Nash (2011) addresses the aspects of the observational documentary, which drive the ethical argument of the article. Nash pays particular attention to the relationship between the filmmaker and the subject, or social actor. The aesthetic aspect of film gives the filmmaker the power to influence the life of their subject, however "the filmmaker is 
an outsider who cannot understand the world of those he or she films. The filmmaker will ultimately take his or her gear and go home" (p. 228). Despite this difficult ethical problem, Nash offers an ethical solution using the framework of Levinas (1998) who says that "by encountering the Other that we are constituted as an individual" and that "ethics is a questioning stance, a critique of those ways of thinking that determine our attitudes to others" (p. 230).

By observing, we are defining individuals in a role they are not necessarily playing. Nash argues that a trusting relationship between filmmaker and subject in observational documentaries preserves the self and Other, despite representation. She writes that an ethical encounter becomes possible when documentarians recognize the input of the Other and the limits of their own understanding. This framework, however, is quite vague, and it is unclear how it can be used in practice, and if it can contribute to the decision-making process in any way.

\section{Filmmakers as gatekeepers}

The relationship between filmmakers and subjects is one of the key issues in the ethics of documentary film. There are at least two aspects to it - the interaction that happens during the process of filming and the way a filmmaker chooses to represent them in the film.

Gatekeepers are people who "regulate the flow of information, language and knowledge" (Storm, 2007, p. 2) and “determine what becomes a person's social reality, a particular view of the world" (Shoemaker \& Vos, 2009, p. 22). Journalists have been traditionally considered gatekeepers by deciding which stories to cover and what information makes it into the story. Documentary filmmakers act as gatekeepers too for 
several reasons including that only a small percent of the footage is actually used in a film.

Maccarone (2010) discusses the filmmaker's role, or obligations, and raises the question of whether or not a filmmaker can intervene in certain situations. She gives an example of a documentary Dope Sick Love in which filmmakers remained idly by as observers during the overdose of a subject. The main reason for a journalists or a documentary filmmaker's non-intervention is that the action "violates their subject's autonomy" (p. 201). However, the presence of the camera already violates this autonomy in a way - it is impossible to be an indifferent observer, especially when a filmmaker spends months with his subjects. He or she becomes part of the reality rather than just observing it.

Maccarone claims that because documentary filmmaking "can be thought to arise from its status as a practice of a social institution" (p. 197) that filmmakers have certain obligations; the most important one is minimizing harm to their subjects. It applies both to the filming and editing process.

Pryluck (1976) addressed many aspects of subjects' representation including disclosure (how much information is used), exploitation (the difference in authority and control of a filmmaker and people filmed), victimizing subjects, privacy, participants' consent, consequences participants face after a film is released, and the rights and responsibilities of a filmmaker. Pryluck writes about collaborative editing as a way to involve the subjects more in the process and avoid exploitation. However he and other researchers (Sanders, 2010; Nash, 2011) admit that it can have both positive and negative consequences on the film. 
Shoemaker and Vos introduce five levels of analysis of gatekeeping forces: individual, routine, organizational, social institutional, and social systems (2009). Analysis at the individual level involves studying a person's background, experience, values, attitudes, and other personal characteristics. Routine analysis focuses on "practices that are emblematic of the field" (p. 31). The subject of organizational analysis is different in media institutions in which gatekeeping roles vary depending on the size, structure, ownership model and other characteristics.

The social institutions level focuses on "forces outside of media organizations" (p. 32) - advertisers, governments, audiences and interest groups. At the social system level the focus is on the scale of how "a country's political or economic system controls the gatekeeping process, as well as influences from the cultural ideology" (p. 32).

Analysis at the individual and routine levels is especially relevant to this research, as I will explore factors that affect decision-making process and ethical challenges that independent documentarians face during filmmaking process. Do filmmakers see themselves as gatekeepers? Do they think about ethics when making decisions and what do they base their decisions on? Do they think documentary film is journalistic? Asking documentary filmmakers questions about the filming and editing process in detail I hope to gather enough information to identify similar patterns and answer the following questions.

RQ1 What gatekeeping forces do filmmakers acknowledge during filming and editing process?

RQ2 What ethical challenges related to the relationship with subjects do documentary filmmakers acknowledge? 
RQ3 What do documentary filmmakers base their decisions on when facing ethical dilemmas? 


\section{METHODS}

Qualitative research is based on the idea that when studying humans we are examining creative processes (Christians \& Carey, 1981). Humans live by interpretations, Christians and Carey write, and the purpose of qualitative research is to study these interpretations. "Methodology must not reduce and dehumanize it in the very act of studying [creative process]" (p. 359). For purposes of this research, which is to study the documentary filmmaking process, qualitative methods seem to be the most appropriate.

The research questions were investigated through semi-structured interviews with documentary filmmakers. I selected six independent documentary filmmakers who produced documentary films in the last three years and screened at major documentary film festivals (Tribeca, True False, Sundance, Toronto).

In-depth interviews allow researchers to explore respondents' perspectives on a particular idea, process or situation (Boyce \& Neale, 2006), and help create a complete picture of a phenomenon or process, provide context and more detail. Semi-structured interviews allowed me to ask follow-up questions and get more details about the most significant parts of filmmakers' experience. In-depth semi-structured interviews also have an advantage of examining filmmakers experience from the raw, as analysis will be based solely on their answers and recollections.

Scholars (Small, 2009; Baker \& Edwards, 2012) do not state an exact number of interviews to provide an adequate sample. Ultimately, it depends on how much 
information is needed to make valid conclusions and see patterns. Six interviews should be enough because the topic of this research is narrow and I presume that filmmakers who were following their subjects with cameras for a long time will have similar concerns and challenges.

The 3-year framework allowed me to get more information about the films since the filmmakers had a lot of memories about the filmmaking and editing processes. The filmmakers were able to remember exact details about the production process because films are often shown at festivals for several years following a film's completion. Sometimes filmmakers even made minor editing changes along the way. The fact that documentaries were screened at major film festivals indicates that they are of good quality and critically acclaimed.

Additional criterion for selecting documentary films, and ultimately the filmmakers, was the presence of strong protagonists because the topic of this research is the relationship between filmmaker and subjects. All filmmakers spent a long time with their subjects, and were able to share a lot of information about ethical conflicts and gatekeeping forces.

All interviews were recorded over the phone, via Skype or in person with a voice recorder. Each interview lasted from 45 to 90 minutes depending on filmmakers' availability.

Visual analysis of selected films was used as elicitation technique. Asking filmmakers to comment on specific scenes and editing choices has helped generate a more detailed picture of filmmakers' motives behind certain editorial decisions. Harper (2002) writes that photo elicitation is more effective than interviews alone because 
remembering is aided by visuals. "Images evoke deeper elements of human consciousness than do words; exchanges based on words alone utilize less of the brain's capacity than do exchanges in which the brain is processing images as well as words" (p.13). In this research, elicitation of particular scenes from films has helped the filmmakers reconstruct the situations and decisions that they made at specific moments of the filmmaking process.

All interviews were transcribed and analyzed to identify any phenomena according to grounded theory (Corbin and Strauss, 1990). Interviewing six prominent documentary filmmakers, all of who have produced a documentary with a strong protagonist, has provided enough material for analysis and identifying patterns.

The questions for semi-structured interviews were divided into 3 categories. More specific questions were tailored according to the selected films and specific scenes in the films.

1. Background information - does the filmmaker have a background in journalism or fiction film? How did filmmaker become interested in the topic of a sample film? How did the filmmaker meet the protagonist? Was it the filmmaker's intention from the very beginning to focus on one subject, or it became clear only at the editing stage?

2. Filming stage - how much time approximately did the filmmaker spend with a protagonist? How would the filmmaker describe the relationships between him/herself and a protagonist (professional/ friendly/ partnership/ close friends)? What ethical dilemmas and challenges did the filmmaker face in the process of filming? Can the filmmaker recall and describe any ethically difficult situations relating to his or her 
role in filmmaking process and his or her role in protagonist's life? What did the filmmaker base his decisions on? Does the filmmaker think he or she has any obligations to the subject?

3. Editing stage - what percent of actual footage actually made it into the film? What difficult editorial choices did the filmmaker have to make? Does the filmmaker think that the protagonist's story was told fully? Does the filmmaker think that the protagonist was represented correctly? Does the filmmaker stay in touch with the subject?

Aufderheide (2012) suggests this approach - not to ask filmmakers to give ethical analysis, but to describe situations that they faced in the process of filmmaking and editing. "Interviewers asked them to recall what they would consider a challenge or conflict involving ethics in their recent work, and allowed the resulting narratives to define what filmmakers understood ethical issues to be.” (p.367). This technique provides data of the filmmakers' creativity, perspectives, concerns, and decisions influencing trends for constant comparative analysis.

One of the challenges of this research was the question whether six people was an adequate number to analyze. However, the topic of this research is rather narrow, and its purpose is to collect and analyze experiences of documentary filmmakers whose films feature one or several strong protagonists. Taking into account that all of the filmmakers chosen for interviews had spent from several months to several years with their subjects, they had experienced similar problems and had faced similar ethical dilemmas.

One of the limitations of this research is that the findings and the data collected are relevant to a narrow pool of researchers exploring documentary filmmaking, and 
could not be applied on a more general scale. In qualitative research it is hard to eliminate all of the researchers' biases. However, having strong interest in documentary filmmaking myself, I tried not to transfer my own filming and editing experience on the research and data analysis.

The data collected using qualitative research methods is usually context-rich, value-laden, and narrative-filled (Kranz, 1995; Velez, 2008). However, for the purposes of this research context was especially important because allowed to examine filmmakers' decisions in different situations and situational factors affecting their decisions.

This research can be validated by means cross-examination using two methods visual analysis and elicitation, and interviews. The research can also be validated by peer review - I asked my colleagues sharing interest in documentary filmmaking to read the research and give opinions concerning the validity of the arguments, findings, and factual support.

For this research project I selected six recent documentary films:

These Birds Walk by Omar Mullick and Bassam Tariq is about the life of a runaway boy in Karachi, Pakistan - who the filmmakers met at a shelter for lost and runaway children. The film also features humanitarian work of Pakistani philanthropist Abdul Sattar Edhi and an ambulance driver working at Edhi Foundation hospital. These Birds Walk is an insightful look at modern Pakistan with its poverty, rich traditions and ongoing hostilities with the Taliban.

E-Team by Ross Kauffman is a portrait of several Human Rights Watch emergency team members whose job is to document war crimes and crimes against humanity right after they have happened. 
Rich Hill by Andrew Droz Palermo and Tracy Droz Tragos follows three teenage boys from very poor families in Western Missouri. The three protagonists have very different personalities, families and heartbreaking stories, but the theme of poverty is what links them.

Marmato by Mark Greco is a film set in a small Colombian mining town where men still use traditional ways of mining - using shovels, dynamite and sulphur lamps. The mountain in Marmato has one of the largest gold reserves in the world. At some point a Canadian mining company started buying all mines in the area to begin open-pit mining, which would mean leveling down the mountain and relocation of half of the town. The central theme of the film is a growing conflict between the locals, the government and the company representatives, as well as disagreements between the locals supporting and opposing the Canadian company's business. Greco spent about six years in Marmato documenting the story as it developed.

Actress by Robert Greene is a portrait of his neighbor, Brandy Burre who starred in The Wire. Greene's main goal was to explore performance in documentary; and an actress by profession and a melodramatic woman in general, Burre was a perfect subject. Life After Death by Joe Callander follows a young man in Rwanda who, as most Rwandans, is still dealing with the aftermath of the 1994 genocide. Irresponsible and not knowing what to do with his life, Kwasa has 'adopted' American parents, Dave and Suzette, who help him out financially and with advice. 


\section{ANALYSIS}

\section{Ethical challenges reported by filmmakers during filming and editing}

\section{process}

In journalism ethics is often linked to accountability (Glasser \& Ettema, 2008).

But if journalists are accountable to their audience, documentary filmmakers don't have such obligations; none of them mentioned the audience as a major factor when making decisions. Yet most filmmakers reported facing ethical challenges where decisions weren't obvious. All of the challenges were directly or indirectly linked to the filmmakers' relations with their subjects. Challenges that documentarians reported included unavoidable manipulation, balancing between staying close versus staying distant with subjects and involvement versus non-involvement in their subjects' lives.

\subsection{Manipulation}

"The second you turn the camera on, you started the relationship so weighty, so heavy that they are either going to perform or not perform." (Omar Mullick, director These Birds Walk).

All filmmakers interviewed for this research mentioned that the presence of the camera in the scene alters the reality and affects filmmaker/subject relationships. "There is a camera there, we all know it, so why hide this fact?" said Ross Kaufman, the director of Oscar winning documentary Born into Brothels. Being honest with the subjects and audiences upfront about the filmmaker's role in the process is important according to the 
filmmakers. All of them admitted to manipulation to a certain extend, as even pointing a camera in a certain direction or choosing a close-up over a wide shot is manipulation in a way; but it is unavoidable. "It's always like you turn on a camera, and you are exploiting the situation by virtue of you pressing the record button." Kauffman said. "I feel like a parasite sometimes."

Robert Greene (Fake it so real, Kati with an i, Actress) shared Kauffman's vision of documentary: "Documentary is exploitative. Period. Because there is an exchange created where I film you, and I'm using that, editing it together to create something that I want to do, which is a movie, and that's an exploitative process."

Most filmmakers said their films were based on principles of 'cinema verite', and that they didn't have scripts or storylines in mind when they had started filming. Most of them admitted to directing some moments. The filmmakers didn't find it ethically inappropriate to ask a person to repeat on camera something he or she did or said earlier when the camera was off.

Andrew Palermo, the director of Rich Hill shared his experience.

We are not telling the kids to do things, but sometimes you set up scenario, you suggest to a kid who talked a lot about something or like 'I haven't seen you do this, you talked about it a lot. You say you love riding your bike so much, so can I see you ride your bike?' Or other things that perhaps might not be as cool journalistically.

Joe Callander (Life after Death) said that he was doing a lot of story editing on paper, and that he didn't think his film was an example of cinema verite. 
A lot of the stuff didn't happen when I needed it to. So I was like "Okay Susette, come with me, we are going here, you need to say this". And its true, everything she said, she said at some time. I just had to have her do it in front of the camera. Callander said that ethics or issues of the truth only concern him "as far as the product, what you walk away with", not the way to get there. "Truth in documentary is all so subjective, and as soon as you make an edit, as soon as you turn the camera on, the truth is gone, the literal, actual truth is gone," he said.

Kauffman admitted that the chronology in his documentaries is second to the "emotional truth".

If you extract someone from the scene because it doesn't help your narrative, but they are actually there, and in another scene they weren't... it is truthful, it just didn't happen at that moment, but it did happen - and for me, and a lot of other filmmakers, we are okay taking these liberties as long as it actually did happen. If it didn't happen, but you are telling people that it did happen, then that's wrong. But if it did happen, but just at a different time... As long as it is really based on truth. I think that's the key.

Although all filmmakers admitted to having to manipulate and direct when filming, none of them saw it as a problem or unethical thing. Documentarians treated it as an unavoidable component of filming. They acknowledged that truth in a documentary is distorted anyways, and moderate manipulation doesn't make films less truthful.

\subsection{Staying distant VS being close with subjects}


All filmmakers said they didn't try to stay distant from their subjects. Kauffman even called his subjects "collaborators" emphasizing that people who are being filmed are active participants and without their contribution a film wouldn't happen at all.

In most cases the filmmakers established friendly relationships with their subjects due to personal reasons - because staying distant was "just not their nature as a person" (Kauffman), or "Just the way that I make things, and the way that I want to work with people" (Callander). However, the filmmakers reported that there are some boundaries depending on who the subjects were. Palermo said that him and his co-director and cousin had different relationships with children who appeared in Rich Hill, which contributed to the process of filmmaking. "I was more of a peer to them whereas she (Tracy Droz Tragos, co-director) was more of a parent to them," Palermo said.

We both had differences and were filling each other's gaps. Just in that way it was great because we could keep... different perspectives coming at them all the time, and it was interesting in that way. But for the most part I tried to stay relatively neutral to them always during filming. Of course I was friendly, and really liked these kids, and admired them, but I didn't want to get too close simply because I wanted to try to be a little bit more invisible while I was filming, I didn't want them to try to talk to me too much. But I do think that ingratiating yourself with your subjects allows them to be themselves more easily in front of you.

Kauffman talked about how filming Human Rights Watch people (E-team) was different from filming children in India (Born into Brothels). Unlike Indian kids who soon forget that there is always a camera present, the protagonists of E-team were professional interviewers. He recalled one episode when he and his subjects were in the 
car, and when he asked them a question they responded: "Ross, it's a very intriguing question.” It was a joke, which showed that Kauffman's subjects didn't really consider themselves subjects and were controlling the situation to a certain extend. Only with time the protagonists became more natural and relaxed in front of the camera.

"They [human rights watch emergency team] know, they are smart, they are interviewers," Kauffman said. "So it was really about breaking it down, getting used to the camera." Later, at the editing stage, one of the editors pointed out how much more comfortable the subjects were with the camera in the end of the filming process, two years from the start. Kauffman mentioned it to Anna Neistat, one of the protagonists, and she said that at some point she thought the film would never be finished, and that the filmmakers were doing it just because it was interesting for them. "And that was great," Kauffman said. “...In a weird way it was sort of a key to her just being herself and not really caring."

All filmmakers admitted to having responsibilities to their subjects, and said these responsibilities were the most important ethical guideline for them during filming and editing.

"I like to connect people through the medium of film," Kauffman said. "If I can get people in this audience to care for Anya, Ole, Fred and Peter (the protagonists from the E-team) and liking them, and feeling like they want to go and have a dinner with them or something..."

Mark Greco, the director of documentary Marmato spent about 6 years in rural Colombian mining town of Marmato making his documentary. It took Greco a long time to build a solid enough relationship with the locals, which made it possible to explore the 
story in-depth. He said initially it wasn't difficult to gain the trust of the local people, and if he were doing a short project, he wouldn't have to put that much effort in building relationships. However, he wanted "to get deep into their lives," so he had to "earn their trust”.

One thing I did in the beginning of the film was I would go to the mine every morning and always bring my camera with me. But many mornings I wouldn't film, or I would film a little bit and put the camera down, pick up a shovel and start working with the miners. That was for two reasons: one was that I could gain their trust, so they knew that I had a real interest in their lives and understanding who they were, but it was also trying to understand what it was like to mine in these conditions.

In the center of Marmato is the conflict between local Colombian miners and the Canadian company, which was buying small mines in the area in order to start massive open-pit mining. That would involve leveling out the mountain and relocating part of the town. When Greco first arrived to the town of Marmato, local miners still had their jobs and were using traditional methods to mine. Greco witnessed the purchase and closure of mines, men losing jobs. And as the conflict unveiled being one of a few foreigners in Marmato, he was suddenly seen as a "representation of what was causing conflict in the town."

It started off rather well, but after pressure became really intense in town, and the Canadian mining company was causing a lot of disorder in the town, suddenly there was a rumor that I was a spy for the Canadian company, and that I was working to gather the information from the miners, from the leaders of the town 
and giving that information back to the company so that they could figure out the best way to move the people. I don't know who started this rumor, but it would seem kind of logical that the company would start that to make my life really dangerous in the town.

Greco said he "kept pushing really hard" to convince the locals that he wasn't a spy and to gain their trust back, but many people were still suspicious about him - he had spent more than 5 years in Marmato already, and nobody had seen his product or footage. Greco said that from the beginning his idea was not to make an "essay, or give some kind of superficial look at the people being affected, and focus more strongly on the mechanisms of the issue." He wanted to give voice to people involved "who don't often get a chance to speak, and show their lives in an in-depth way."

"The idea for me is that the film is going to be so much more powerful if you are tackling the heavy social issues, but you are doing it in an empathetic way," Greco said. He added that he was always very cautious about the way he approached his subjects and the way they were presented in the film. This is how Greco described his concerns:

I think if you have any kind of understanding or tend to trying to understand the lives of the people on which you are reporting on, you have to also understand a bit of the risk that they take to speak with you, to put their voice to magnify their voice beyond what maybe is just, they would say, in their home. They are taking a big risk, and I understood it from the very beginning of starting Marmato because Colombia is a country in which your word can get you killed very easily. All filmmakers said they maintained somewhat close relationships with their subjects. Most of them did it naturally, and a few mentioned that it benefited the story in 
the end. Most filmmakers acknowledged that they needed to find a balance between being friendly and not getting too close (Palermo, Greene). All of them said they had to find a unique approach to the subjects in each film in order to be able to tell in-depth stories.

\subsection{Involvement versus non-involvement}

Several filmmakers reported facing ethically challenging situations where they chose to directly intervene in a situation. Mullick said in the process of filming, he and his co-director found out that a night watchman at the house for runaway kids in Karachi, Pakistan was beating children. The filmmakers reported him, and the guard was fired. "Kids were involved," Mullick said. "At some point you have to throw the manifestos out and do what's right."

Palermo recalled an episode when one of the teenagers they were following while filming Rich Hill "was suicidal". He and the co-director doubted whether or not they should notify someone who might help, because they thought it might have resulted in all children being taken away from the family. In the end they decided to reach out for help, and found a person both experienced in dealing with such problems, and familiar with the family's situation. The story of this teenager didn't make it to the final edit.

Another ethically challenging situation that Palermo recalled was connected to one of the three protagonists. In one of the interviews, Harley, 15 said he had been sexually abused by his stepfather, and that his mother was in prison for attempting to kill the molester. The filmmakers knew that the boy's mother was in prison for attempted murder, but didn't know the circumstances. "Harley came out about it pretty early in 
filming, in an interview on camera." Palermo recalled. The filmmakers made sure that the boy didn't mind that part of his story being in the film.

When he said it on camera, we set the camera down and said 'Harley, we don't want to exploit you in any way, we want you to know that this is going to be seen by a lot of people most likely... We don't need to share this information, but it's up to you, if you want it to be part of your story...' He is very comfortable with it, and wants people to know because, I think, he feels there is a great injustice done to his mother, and he sort of had a lot of pride about where his mother is for him. All protagonists of Robert Greene's films (Fake it so real, Kati with an i, Actress) were somehow connected to him. One of the wrestlers in Fake is so real is his cousin, Kati (Kati with an i) is his half-sister, and Brandy Burre (Actress) is his neighbor. After he finished editing Kati with an $i$ it turned out that she was pregnant the whole time during filming. Greene said he was puzzled by how to deal with this revelation. "It's a movie about my sister anyway where she kind of looks dumb, but she is kind of beautiful, and then this crazy thing happened that changed her life," he said.

Greene said that before starting filming Actress he had some concerns. His two earlier films were about people close to him, and he didn't want it to become the only thing he does. But his desire to explore the idea of performance in documentary pushed the project forward. Greene said that Burre, the protagonist, was theatrical in the film because of her personality, not profession. "I think that camera makes people perform," he said. "I think the camera makes things intimate in a way that is sometimes unsettling, I think that also camera becomes like a therapy session for some people.” Speaking about 
Actress in particular, Greene said the film worked largely because of his emotional ties with Brandy.

I'm very well versed in dealing with intimate things to make it a film. The way I deal with it is to be abrasively honest upfront - I'm going to make a movie where you are going to become a character of your own life, and that is going to be alienating in some ways and really cool in other ways.

Greene happened to start filming when Burre was going through a rough period in her life separating with her husband and trying to get back into acting. Greene didn't have Burre or her husband sign a release form before the film was completely done. He said either of them could "shut the whole thing down" at any time because it was a very intimate and explicit portrait of the family.

Two subjects of Callander's Life after death were a couple (Dave and Susette) he was working for as a videographer, who also commissioned him to make the film. He said he thinks the fact that his sponsors were his subjects "really takes people off-guard" because "it's not done very often and people don't quite know how to deal with it." He said for him it was not an issue because the film doesn't differ from how he normally communicates with people.

That's how I interact with Dave and Susette in real life, so why not do that in movies. And I think its going to take a little while because people's focus is the satire, or whatever, but its not. I am not a satirist. That would make for a very short career as a filmmaker, a documentary filmmaker. But, I don't know, I just think that people are funny and life is strange, so lets have a laugh. 
All filmmakers acknowledged that their subjects' wellbeing comes before all other things. To get involved or not if it is clear that one of the subjects needs help is out of question. However, the main challenge was how to interfere in a way that would be beneficial for the subjects.

\section{Decision-making process}

All filmmakers reported that ethical decisions they make during the filmmaking process are largely based on the situation, subjects and filmmakers' personal experience. All documentarians acknowledged their commitment to truthfulness and telling people's stories, the two things characteristic of journalism (Kovach \& Rosenstiel, 2007; Davis, 2010). However, none of the filmmakers rely on ethical norms or codes, or consider what they are doing to be journalism.

\subsection{Situation and subjects}

All filmmakers acknowledged that ethical decisions they made were largely based on a situation and people they were filming. Kauffman said that each film is different, and speaking about establishing close and friendly relationships with subjects he said that "with these verite films, this one (E-team) and few of the others that I've done it sort of felt right to me."

Kauffman mentioned how outside factors often interfere and can change the initial concept or idea. His plan was to make a film about Human Rights Watch investigators and their work. The first meeting that Kauffman attended at Human Rights Watch was dedicated to Pakistan, and he and the co-director thought they'd go follow their subjects to Pakistan. But a few days later Arab Spring started; the focus of the organization changed and so did the focus of filmmakers. 
It took Kauffman and his team longer to raise funds for the filming of E-team because the donors who sponsored his previous films were not impressed by the idea of a documentary about Human Rights Watch. Kauffman said they probably thought it would be a promotional film for the organization. Finally Kauffman managed to prove that what he was doing was an independent film, just like his previous one.

If we'd gotten funding in February or March, the whole film would have been mostly about Peter (a Human Rights Watch expert who worked in Libya) probably, and partially a little bit with Syria dropped into places. So it's really fascinating how so many different things are making this kind of film, dictate what the film ends up being.

Mullick recalled that he and his co-director initially planned to make a film about a Pakistani philanthropist Abdul Sattar Edhi. He said he wanted to "shoot something where you push intimacy, empathize with the characters, and that really drove me to want to make that film the way you see it where the vérité is really the cornerstone." When Mullick and his co-director Bassam Tariq arrived to Pakistan after making a verbal agreement with Edhi during his visit to New York, they faced an unexpected challenge. Edhi said he didn't remember them, and didn't know anything about their agreement. “And at that point I quit my job," Mulick said. "I sold everything, and I bought the cameras, and I've burned all these bridges." But Mullick and Tariq didn't leave. They were coming to see Edhi every day hoping to film something until one day "this creative conceit came up." Mullick recalled, "he (Edhi) said it, come look at the people." Mullick and Tatiq stayed and started filming at Edhi Foundation's facilities - runaway homes, orphanages and hospitals. On the first day of filming they met their main protagonist. 
Callendar said that he was asked to make a documentary portrait on another person, but "he was very quiet and it wasn't really clicking". But when he met Kwasa, the protagonist, he thought Kwasa was "the most outrageous person in Rwanda," so Callander wanted to spend more time with him and film. "I am drawn to kind of crazy people," he said. "I think that's my burden in this world. To tell their stories and bring them moments of grace."

Most filmmakers admitted that their subjects' best interest was a key thing in decision-making process. Greene said that the two protagonists from The Actress, Brandy Burre and her husband Tim didn't sign a release form until they saw the film. "That was an important structural thing to put in play, so they never felt trapped," Greene recalled. "Even though, I think that in the end they would not have been able to pull out, unless this movie was atrocious." Greene started filming when Burre and her husband were separating. He admitted that Tim was "the key ingredient" and that he "could have shut the whole thing down the whole time." Greene said that the fact that Tim went to film school was somewhat crucial for Actress to be finished.

Because [Tim] went to film school he has an appreciation for the form of filmmaking and one point he watched it, and he said, "I think that it is a great movie, I never want to watch it again. I hate that it exists, but you made a great movie" and then he started talking about his character in the movie in a way that I thought 'wow you really can separate yourself from this'. If Tim was any normal guy in that situation, he probably would have shut the whole thing down and if Tim wasn't in it there would be no movie. 
For Greene responsibility to the subject "is probably the most important relationship a filmmaker has". He said that one of his main concerns was how Actress could affect Burre's children who also appeared in the film, that they are "not blindsided by the film", and when they grow older they would understood why Actress was made. "Everything else goes away at a certain point," Greene said. "Movies disappear, everything else goes away, but those people's lives that you are affecting are the most important relationship you have."

Greco mentioned several times that while working on Marmato he was very cautious about his subjects and the risk they were taking by letting him into their lives. This fact influenced his decision-making process. Another important factor was his desire to tell an in-depth story about the place and its people. He said that Marmato was not the first mining town he visited, but in many other similar towns across Latin America all mines had already been purchased by Western companies. But in Marmato this process was only starting and the majority of miners were still using traditional mining methods.

Recalling dealing with ethically challenging situations Palermo also mentioned that he had the subjects' best interest in mind. The filmmakers' decision to seek help for the suicidal teenager, not to ignore it or simply report the family to the authorities, as well as making sure the sexually abused teenager wanted to share his story fully on camera, suggests that Palermo and Tragos were basing their decisions on the subjects' wellbeing rather than on breaking a story or creating a sensation.

Most filmmakers reported that they often based their decisions on the situation and their personal experience and views. The crucial factor in decision-making process, however, is the responsibilities to their subjects that all filmmakers acknowledged. All of 
them mentioned thinking about the subjects' best interests when facing ethically difficult situations.

\subsection{Ethical codes and documentary's relation to journalism}

All filmmakers acknowledged their commitment to telling the truth and constructing a true story, however their understanding of 'truth' and the range of means used to tell the story is broader than those used in journalism.

Kauffman said that journalists are often held to a higher standard as far as chronology and manipulating with narrative goes because of the definition and the purpose of journalism is different - "to inform people about what happened, as opposed to emotionally move them. That's what essays are for, that's what op-eds are for. Films are sometimes more like op-eds." He added that the word 'documentary' "doesn't really

do the form justice." He called documentary genre "non-fiction films" or "narrative nonfiction."

"There are different forms of documentary," Kauffman said. "But for me, I'm telling a story... I'm trying to find characters and great stories in order to tell their story, to engage with people. Is it journalism?"

Mullick said he "really resists" the idea of categorization between documentary filmmakers and journalists, "as if somehow the category or this label afford you what some people call the liminal space, an area which inhabits its own ethics." Mullick shares the main postulate of virtue ethics. "I think first principles of ethics is a human being," he said. "I'm transparent about my biases, what I would like to see... Because you have a certain vocation the ethics doesn't change." 
Mullick mentioned experience and personal qualities as a factor that can affect the decision-making process. He talked about war reporting where the stakes are "literally life and death" and when professionals should "be done with all manifestos what make good or bad." He said that in such circumstances "you are either of some use to them in your reporting, or you are not. You are either trying to do something to the best of your capacity or you are not."

Mullick talked about war photographer James Nachtwey as an example. He was wondering what would Nachtwey do in a critical situation, "would he put the camera down, would he do something to help somebody, or would he take a photo". In one of the interviews Nachtwey said he always puts the camera down. "This kind of restored my faith in humanity," Mullick said. "Separating out that label allows people to stand in Beirut and Syria and take photos while someone is dying because the ethics is different when they are there, or so they claim."

Mullick added that what appealed to him most about Nachtwey's position was that he was "a human being first, so he sees someone else about to die, and he tries to help them. And if he can't, he's got a camera, so he can show what's going on, something that he couldn't change."

Palermo said he thinks that documentary film and journalism are "quite distant in vision", and that it is "uncomfortable to some people how much of documentary is directing". He said he made decisions on "case-by-case basis" and didn't have any codes or guidelines in mind. 
Palermo mentioned in the interview that when him and Tragoz submitted their short film ${ }^{2}$ to New York Times' Op-Doc ${ }^{3}$ they had to follow a strict guideline, for example they couldn't “affect the timeline of reality too much, manipulate shots, flop them or reverse."

Greco said that it is often hard if not impossible to reproduce such a complex issue as the situation in Marmato in 20 minutes and "if you only come for a week and spend a couple of days with these people." He added that many people might not have the same opportunities financially or time-wise to do what he did, and that there are different ways of doing it. But with Marmato and similar cases "is so much more valuable when you can give time to the story and give time to the people in the story, because then you can hopefully create something that can generate a dialogue that's productive." Otherwise it would only be "a superficial glance" on the story, Greco said.

To me it was really important that audience members feel like they really getting a sense of what it's like to be somebody living in Marmato regardless of the issue, that you are really feeling this connection, that I really feel like I understand their lives, and what they want in their lives, and how they rationalize that.

2 "Sarah's Uncertain Path" is a 5-minute long documentary about a pregnant teenager in rural Missouri. http://www.nytimes.com/2014/01/22/opinion/sarahsuncertain-path.html

${ }^{3}$ Op-Docs is the New York Times opinion section "for short, opinionated documentaries, produced by independent filmmakers and artists with wide creative latitude, covering current affairs, contemporary life and historical subjects." http://www.nytimes.com/video/op-docs/ 
Greco's ideas about encouraging a dialogue using his film, and making people outside Marmato care about the issue resonated with Kauffman's idea of "emotional truth" and "connecting people through the medium of film."

Sometimes it's not perfect chronology; sometimes you work with chronology to tell the emotional truth and to create a narrative. For me it's always about the emotional truth, really getting to the heart of that. That's what I want to do. The word journalism doesn't really factor in what I do that much. What other people do sometimes, yeah. That's the other thing; there are so many different types of documentary.

Mullick also said that for him the goal in documentary is audience empathizing with characters.

I don't think that's journalism. I mean you can get all philosophical about it, say 'report back from the soul or something', you know get corny like this. I'm reporting, but I'm reporting on these people, so you connect with them, and spend 90 minutes with them.

Callander used Werner Herzog's phrase "ecstatic truth" to describe the main objective of documentary as a genre. According to Herzog, ecstatic truth is "a kind of truth that is the enemy of the merely factual." Poetic and mysterious, it "can only be grasped with effort; one attains it through vision, style, and craft." (Herzog, 2010). "I don't really care about issues of objectivity, we are just telling stories," Callander said. "We are trying to get to the ecstatic truth, not report the actual truth, because that would be boring as hell." 
The truth is endless, in either direction, if you go out far enough. And you can tell the truth, or you can say something true. And if you say something is true, you might have re-contextualized a lot of stuff, and put stuff in a way that didn't happen, but you arrived at something that is true.

Callander admitted that half of his footage was directed, and that it wasn't true "in a journalism sense", but it happened "at some point in reality". "For me ethically, or issues of the truth only concerns me as far as the product, what you walk away with, if it's something true," Callander said. For Callander documentary is subjective. "As soon as you make an edit, as soon as you turn the camera on, the truth is gone; the literal, actual truth is gone," he said.

Greene said that he considers documentary "art that relates to journalism". He used the phrase "moving idea of truth" or "constructed truth" referring to documentary. "Truth in the film is a constructed idea of truth," he said. "Although you are dealing with reality which is a broad chaotic truth", and documentary filmmaking is "the act of putting frames on this broad chaotic truth" which is a manipulation. He shared part of his experience while making Actress.

She just got busted for cheating on her husband. It is painful and that's a crazy reality, and it's crazy that I am able to eavesdrop on this. But it's crazy that she is embracing this storytelling and this thing sort of happens in a different way than the supposed objectivity. I think that movies tend to be, because they are manipulated by nature, they tend to be bad journalism.

Greene doesn't favor the proposals of ethical codes for documentary filmmaking as he resists "any idea of putting a code on art". He added though that "unethical 
filmmaking should be attacked vigorously", but the big question is how to decide what is ethical and what is not. He said that for some people "The act of killing"4 might seem unethical because of its brutal reenactments, but for others "the ends justify the means". The ends are usually creating an appealing and truthful story.

Although all filmmakers resisted the idea of having an ethical code for documentary, they admitted to facing ethical challenges and taking tough decisions. Committed to telling true stories, they have their own interpretations of truth, which act as guidelines in a decision-making process.

\section{Gatekeeping}

The filmmakers were not asked directly to name gatekeeping forces they encounter in the process of filming and editing; however they acknowledged many factors that influenced their decision-making process, which can be considered gatekeeping forces. As craftsmen of their stories, filmmakers inevitably act as gatekeepers.

Most gatekeeping forces acknowledged by the documentarians are on individual and routine levels of analysis (Shoemaker \& Vos, 2009). Some of the restraints that all filmmakers mentioned, like their commitment to creating a truthful story, taking audience into consideration and being cautious about characters' feelings can be considered routine forces where "industry standards" (2009, p. 51) are key. However, there are no established standards in the documentary industry, and all filmmakers acknowledged in

4 "The act of killing" is a 2012 documentary film directed by Joshua Oppenheimer, and co-directed by Christine Cynn and an anonymous Indonesian. The film focuses on Indonesian anti-communist purge killings of 1965-1966, which left more than 500,000 dead. http://www.imdb.com/title/tt2375605/ 
the interviews that they based their decisions on the situation and as their personal experience and beliefs, which are characteristic of the individual level.

All films studied for this research screened at major film festivals such as Sundance and True/False, which don't have any requirements for the films' content except for that the films should be non-fiction, not "entirely scripted or improvised fictionalizations of actual events". Some festivals also "encourage chimeric works that straddle the line between non-fiction and fiction. ${ }^{, 6}$ All of the interviewees are independent filmmakers, and their films weren't commissioned by specific media. There was no mentioning of direct restrictions imposed on organizational, social institutional and social system levels (2009).

The main gatekeeping forces reported by the filmmakers on the individual level included the strife between truthfulness and aesthetics, relationships with subjects, personal beliefs and vision of the story.

\subsection{Crafting a truthful story: ethics and aesthetics of documentary}

“Don’t Lie is a big thing," Greene said speaking about basic guidelines for documentary filmmakers. "But lying is a very specific thing. In film truth is a construction.... It can be constructed multiple ways."

All filmmakers agreed that documentaries in general should be truthful, but offered their own interpretation of truth in documentary - "emotional truth" (Kauffman), “ecstatic truth" (Callander), “constructed truth" (Greene).

\footnotetext{
${ }^{5}$ Rules and regulations for submission; Sundance Film Festival. http://www.sundance.org/pdf/submissions/2015_Submissions_Rules.pdf

${ }^{6}$ Call for entries; True/False film festival. http://truefalse.org/submit/features-and$\underline{\text { shorts }}$
} 
"You capture something that is amazing, and then your job is to take this amazing thing and make it make sense," Greene said. "And by making it make sense you have to manipulate and distort." For all filmmakers some level of manipulation is acceptable if it helps the story develop, but there is no agreement on how much manipulation and distortion is too much. "Where do you draw a line in terms of the actual truth of what's going on or not, and how you manipulate the actual real facts of the situation?" Kauffman posed a rhetorical question. His answer was that "each filmmaker and each journalist is going to do what they feel right."

Callander's film was set in Rwanda, and the protagonist's father was in prison “for killing the people during the genocide." However Callander didn't want his film to be about genocide.

If I would go over there and try and make a genocide film, its like, that would just be completely embarrassing and inappropriate. I'm a white, middle class American, trying to tell a story about something that happened in Africa, 20 years ago, that I wasn't a part of and I knew nothing about. All the reporting has been done. If you want to learn about the genocide, go watch PBS or whatever. I mean if you want to get to the truth of anything then go through people's personal stories, just re-hashing the statistics wouldn't have been of any value to anybody. Callander said that genocide and memories of it are still a big part of people's life there, which is clear from the film; but it was not Callander's intention.

Basically I made the type of film that I want to be making and I just happened to do it in Africa, I would have done the same thing here, I want to tell that same 
kind of story where its just very funny. That's how I see the world. It's not maybe funny, but just a little absurd...

According to the filmmakers, aesthetics plays as important part in the filmmaking process as ethics. Filmmakers acknowledge that the two concepts are interconnected. "I am constantly thinking about the role of aesthetics and ethics," Greene said. For him understanding the nature and mechanisms of manipulation and distortion "allows you in a way to manipulate and distort if you did it properly, if you do it for some sort of higher thing”.

Actress was Greene's experiment and exploration of the idea of performance and "how documentaries are full of performances". He thought it would be interesting to film "a very theatrical human being, an actor." He said that Burre is "melodramatic" in general. "She would be theatrical if she never went into acting," Greene added. He described the strategy he used while making Actress as "layering the subjectivities."

Sometimes Brandy is performing in this way and sometimes she is being authentic in this way. Sometimes I'm using this technique and sometimes I am using this technique, and they sort of layer against each other and you really get the sense of a moving idea of truth.

The opening shot of These birds walk pictures Omar, the protagonist, running into the ocean at dusk. It was true because it happened, but the filmmakers were the ones who made it happen. When they were driving Omar home together with the ambulance driver from Edhi foundation, they found out that Omar never saw the ocean even though Karachi, the town where the film takes place, is located on the beach. Before taking the 
boy home they made a stop on the coast. That scene was praised by critics $^{7}$ for reflecting the atmosphere and the complexity of the subject of the film; and it is an example of how ethics and aesthetics intertwine.

Filmmakers are gatekeepers: each of them has a unique understanding of ethics and vision of aesthetics, and each finds a unique balance between the two in a film. Documentaries are stories of people (subjects) told by other people (filmmakers), and every time a story is told something changes because all storytellers use different means to bring the ideas home to the audience. These means as well as storytellers' vision of truth, ethics and aesthetics act as gatekeeping forces.

\subsection{Subjects matter}

One of the biggest gatekeeping forces shaping the story was filmmakers' relationship with their subjects, especially in documentaries that featured underserved people. Greco said that in his film he tried to give voice to the people who didn't get a chance to speak. He was very cautious while editing because he had to present his subjects "in a way you told them you were going to present them", and not make them more vulnerable.

Mullick said that he "bonded very quickly" with Omar, the runaway boy and protagonist, and that he "got very protective" of the boy. Mullick also acknowledged that he stays in touch with his protagonist helping the family financially. "We helped them out with money and stuff," he said. "We are trying to set up an education fund in a school

7 Ward, A. (2013). These birds walk: a misheard lyric.

http://www.uniondocs.org/these-birds-walk-a-misheard-lyric/ 
so that he can actually get an education. He also has to want to do it, so hopefully he does."

Palermo said he and the co-director avoided showing some harsher realities in the film not to distance the audience from the subjects. "We were very careful not to show so many shots of broken windows and snow coming into the house, we were careful not to show a much more heated argument than shown in film," he said.

Palermo mentioned that for him discovering that all people featured in Rich hill liked the film was very important, and the complements he received in the media “didn't feel as good as knowing that they [the protagonists] all really loved it."

They appreciated the realness of it in the end. I think it's one of the things that characters understood - they loved it because it's raw and it's real. And I really appreciated it indeed. We can notice that there are some flaws in this family, but it's the real deal, it's not like we are sugarcoating it or making it something it's not.

Kauffman said that he wants the audience to care for his subjects. Greene described Actress as an "intimate portrait". For him making sure that Burre and her husband were comfortable with the film and “didn't feel trapped" was very important.

Callander made his film about Kwasa because he thought his story and personality was interesting. "I mean I love the guy, we're friends," he said. "I would certainly say we are friends, its funny to say that, now that I say it out loud, yea. I think you could say that we are friends." Callander also keeps in touch with Kwasa.

Having bonded with their subjects, filmmakers, deliberately or not, transformed passive "subjects" into more active "collaborators" as Kauffman put it. Documentarians 
didn't just observed the protagonists say or do something and captured it on tape - they communicated with them, learned about their worries, concerns, vulnerabilities and secrets. This communication process shapes the story as it develops. The more time filmmakers spend with the subjects, and the more they become parts of their life, the more caring and sometimes even protective they become. These bonds act as gatekeeping forces in a way, because if the filmmakers spent less time with the subjects or stayed distant, their documentaries would have been different. Not better or worse, not necessarily more objective and true; just different.

\subsection{Filmmakers' vision of the story and personal stance}

Another gatekeeping force acknowledged by the filmmakers was their personal beliefs and vision of the story. "Filmmaking is just the filmmaker saying something, that's all it is," Callander said. "And why don't you just say it in the most distinct and bold way that you can come up with?”

Most of the filmmakers spent substantial amount of time with subjects and had hundreds of hours of raw footage. Mullick and Palermo said that had several more people they filmed, but their stories didn't make it to the final cut.

Palermo said that they followed five families with many kids in each, but they didn't want the film to be "just a long document of these families". For him it was important to have "three distinct characters so to speak." "I think they are all circling with different things," Palermo said describing the three protagonists. "But all sort of fall under the umbrella of poverty in America, and that's there right now." 
Mullick said that they had "about 4 more characters, ... spent years shooting, and they all ended up on the cut footage. He added that he wanted the film to be "more like a turn poem.”

I had this idea of basically following for a day all these people who were connected very loosely. And that day happened to be that pivotal day when Omar goes home, and there are all these voices in the city... Some people think that if we had that other stuff, it would dilute the story that we do have of the runaway boy. I don't know about that. I think sometimes people tell themselves things to feel better. We didn't do that because it would be worse... It's just different. Mullick said he prefers "films where characters are not squared off or labeled," which applies to both fiction films and documentaries. He said that "complicated, layered, surprised" are "what brings truth".

"I'm not saying it is truth, I'm saying that it resonates with me," he noted. "And I think there is more window there too for people to empathize and attach themselves to a character, because people are complicated." He spoke about one of the scenes from the film as an example.

That's the scene that I love at Edhi's. This guy is a living saint, but he is eating his cereal and he is dribbling on his chin. And I like that. It's a bit cranky. It doesn't make the philanthropy any less relevant; it just means that he is a full human being.

Greco communicated a similar idea. "It's very easy to present a character in a way that's one sided," he said. "So it's a lot more difficult to incorporate the natural complexity of being a human being which you have to find in that footage that you 
filmed." He said that he wanted to have a person who was against the Canadian company mining in Marmato, and a person who would be in favor to show the division in town; but then he was looking for somebody "in the middle, not sure where he was." Greco recalled how his opinion on the issue changed with time.

When I started the film I had a rather radical opinion about the situation. I thought it was wrong, and I thought it (the Canadian company owning the mountain and the mines) was not the right way for the future of Marmato to play out. But after spending years working there the people themselves taught me how complex the situation was, and I also went and I sought out to try to talk to the people on the other side of that problem that maybe before I wouldn't have talked to.

Greco also said that later he realized that his opinion is "of very little importance if not of zero importance", and the people of Marmato are " in power that can save their town or determine the best future for their town", so the best he could do is give them voice.

Kauffman said that he and the co-director had to delete of a scene about how Anya, one of the protagonists met her current husband Ole. He recalled the scene. They met when they were in Chechnya in 2009 during the war, and they were detained together. And Ole thought Anya was married, he just assumed she is married. And he tells the story, "I thought she was married. I was very attracted to her, but she was married, so I thought it was not going to happen.” And they got detained together. And while being detained, there was one other person there, and they were talking, and the other person said something that was 'hey Anya, 
does your ex-husband know where you are now..." And he was like 'ex-husband?" And, you know, very shortly after that they got together.

"It's a great scene," Kauffnam said. "We just couldn't include it in the film, it didn't help the film move forward." The film ends with Anya and Ole in the hospital after she gave birth to their baby. The last scene features Anya talking on the phone, just a few hours after giving birth. The call was an interview or comment inquiry, and Anya was reluctant to say she wouldn't be available. Instead she asks about the day and time. "I'm very proud of the last scene," Kauffman said. But he had to insist on this scene being the closing one.

There was one cut of the film where I went to the editing room, and it wasn't there, the phone call, it was just the birth. And I'm like "Where is the phone call?" And my editor, a really sweet guy, was, "do you really wanted to end on that?" And I was like "Absolutely! We have to end with this phone call”... And he is a great, great editor, but he just had this idea, that we might not want to end with a phone call. But that's the whole point of the movie - they go back to work. Filmmakers' personal beliefs and visions are among major gatekeeping forces affecting the filmmaking process. As Greene said, the truth in documentary is only a construction of truth. Interaction with subjects, circumstances, discovering new facts influences filmmaker's vision and personal stance, and the film is a product of this complicated communication and exchange process between filmmakers and subjects. 


\section{CONCLUSION}

There have always been more questions than answers in philosophical discussions on ethics in general and media ethics in particular. SPJ code of ethics provides guidelines on making ethical decisions for journalists, but often they are insufficient. There is no similar code or guideline for documentary filmmaking, and the industry professionals don't consider it a bad thing. However, as documentary evolves, gains popularity and becomes a source of information about the world for the audiences, the discussion of ethics in relation to documentary becomes more important. Documentary filmmakers generally acknowledge significance of ethics in their work, but oppose the idea of putting any explicit restrictions on the industry.

Through semi-structure interviews with six prominent independent documentary filmmakers, this study examined filmmakers' relationships with their subjects, and how these relationships influenced ethical decision-making. The study also explored gatekeeping forces affecting the decision-making process.

\section{Primary findings}

After the analysis of the interviews, the following phenomena emerged.

- $\quad$ Filmmakers admitted to directing and manipulating the shots to a certain extent. They don't consider it unethical because it's unavoidable, but at the same time all of them acknowledged that manipulating too much is not the right thing to do.

- $\quad$ Filmmakers had close relationships with their subjects and didn't try to stay 
distant. All of them were concerned about their characters' wellbeing, and in critical situations they chose to intervene and help the subjects versus observing or recording.

- Documentarians are committed to telling truthful stories. They also want these stories to be beautiful and visually interesting. The conflict between ethics and aesthetics is one of the challenges documentarians face in their decision-making process.

- $\quad$ Filmmakers don't consider what they do journalism. They acknowledge some similarities with journalistic work, but oppose the idea of an ethical code for documentary.

- $\quad$ Subjects matter a lot in the decision-making process. The filmmakers were making sure their subjects were not harmed in any way by their films, and that the subjects were satisfied with the way they had been represented.

- $\quad$ Close and often protective relationships with subjects act as a gatekeeping force in decision-making process.

- $\quad$ All gatekeeping forces acknowledged by independent filmmakers are either individual or routine level forces. Some of the most common gatekeeping forces are individual vision of the story, personal background and experience and strife between truthfulness and aesthetics.

\section{Theoretical implications}

The interviews revealed that the filmmakers have a similar perception of documentary as a genre. They are more likely to treat documentary as art. However, they tend to resist labeling and categorizations. They deny the idea of ethical codes, and at the 
same time condemn "unethical filmmaking" - manipulating too much, and using the footage to prove a certain point of view instead of telling a story and letting the audience come up with conclusion. These ideas echo Krawitz's (2010) findings.

Ethics is a quite broad and vague field of research. Because "rights" and "wrongs" are subjective, culture and context driven, ethics cannot give exact answers - it can only facilitate conversation. Many researchers (Plaisance, 2008; Aufderheide, 2010) write, however, that such conversation is essential for documentary ethics.

According to documentarians their main goal while making a film is to connect the subjects and the audience, to make the audience interested in the subjects' stories and care for them.

The filmmakers' approach to documentary reveals a blend between Nichols' (1992) interactive and observational modes. While trying to depict reality and present their subjects' lives as they are, the filmmakers actively interact with the subjects behind the camera. While Nichols (2006) suggests that filmmakers should focus on both subjects and viewers in their ethical decision-making process, the filmmakers usually say that the audience is usually secondary in their decision-making process.

Nichols argues that in connection to the viewers the line between ethics and representation becomes important; and a question of the extent to which we are "responsible for the truthfulness" (2006) is raised. In filmmakers' relationships with subjects the important line lies between ethics and power - to what extent it is acceptable to expose the subjects.

Filmmakers resonated some of Nichols' concerns. They acknowledged sharing some commitments and responsibilities with journalists (truth telling and protecting the 
vulnerable), however they consider documentary fundamentally different. Documentaries are long-form narratives, and unlike journalism, they don't have to inform "citizens in a democracy" (Craft \& Davis, 2012).

In relation to journalism and documentary the term ethics brings about talks about the concept of truth in a philosophical sense. Many documentary filmmakers have their own interpretations and ideas of truth, which they express in their films. And many of these ideas are unique, thought provoking.

The majority of documentary filmmakers oppose ethical codes, but agree that documentarians should have some ethical standards. By opposing codes filmmakers are protecting their creative process, their abilities to construct truths. However, because constructing truths and carving the story involves other people - subjects, characters or collaborators as different filmmakers call subjects, ethical questions emerge.

Nichols (2006) argued that the "imbalance of power" between the filmmakers and their subjects necessarily raised ethical concerns. The filmmakers studied here acknowledged this imbalance, but said that they approached the issue on a case-by-case basis. Their ethical decisions were based on a combination of experience, logic and intuition. When talking about specific situations, which presented some ethical challenges, most filmmakers could provide arguments to support their decisions. At first they might have say that it felt right at the moment, but revisiting such situations later in a conversation they usually named several reasons for acting the way they did.

This research indicates that individual filmmakers have their personal ethical guidelines that they use in challenging situations. But these guidelines are flexible, and might vary depending on the topic and subjects. Most decisions taken by filmmakers are 
based on individual characteristics, and the main gatekeeping forces affecting filmmakers' decision-making process were reported on individual level.

Some filmmakers briefly mentioned gatekeeping forces at the routine level. When producing documentaries for specific media outlets filmmakers had to follow rules and guidelines based on journalism industry standards.

Even though the filmmakers interviewed didn't mention film festivals as institutions affecting their production process, they might be a gatekeeping force at the social institution level. Usually film festivals that show independent documentaries don't have any requirements content-wise except for that not more than a certain percent of footage can be directed.

However, festivals' juries probably have some standards they apply when selecting the films. The question whether or not these unspoken standards are affecting documentaries at the production stage, and therefore are social institution gatekeeping forces, can be an interesting topic for further research.

The main idea of gatekeeping theory, that there is an individual between a story and its audience, is somewhat true for documentary (Shoemaker \& Vos, 2009). None of the filmmakers denied their role as craftsmen of the message, manipulating the footage to an extent and selecting the scenes they thought were the best. However, all of them acknowledged that their relationships with subjects and the subjects' wellbeing were a crucial factor in decision-making process. Filmmakers made sure their subjects weren't threatened or feeling insecure because of what they said or did in the film. All filmmakers were very satisfied if their subjects liked the documentaries they appeared in and the way they were presented. 
While traditional journalistic gatekeepers and the filmmakers studied here both experience gatekeeping forces applied by sources, they differ in at least one important way. Cassidy (2006) argues that official sources are believed to be gatekeepers because journalists generally consider them, together with the power structure of society, to be valid and trustworthy references Traditional view of journalists, sources and news organizations being the main gatekeepers forms a top-down gatekeeping model (Schramm, 1960; Tuchman, 1978) where the more privileged actors have more control over news. Bruns (2011) suggests that new actors in journalism including stringers, citizen journalists, and more active audience participation in digital journalism facilitate the shift to a more equal collaborative model. This model brings less empowered people to the gatekeeping scene.

In documentary subjects are usually the least empowered people, and yet they can influence the final product, which doesn't fit the traditional top-down model, and relates to collaborative model.

The final decisions about the storyline, interviews and scenes are made by filmmakers. However, by establishing close relationships with their subjects, documentarians indirectly make them a part of filmmaking process. This phenomenon can be viewed both as a positive gatekeeping force because documentaries are stories of real people, often from underserved communities, who probably shouldn't be made more vulnerable than they already are; or as negative gatekeeping force because by protecting the subjects too much documentarians might avoid certain details and the story wouldn't be as full and truthful as it could. Based on these findings more research can be done to 
explore the role of subjects as a gatekeeping force in documentary film, and how trust relationships between filmmakers and subjects may be reflected in the story.

\section{Practical level}

The empirical data collected in this research can help scholars and filmmakers find a common ground and better understand the mechanisms of documentary genre which situations filmmakers consider to be ethically challenging, what they base their ethical decisions on, how they build relationships with the subjects, and what they generally think about documentary as a genre.

A constructive dialogue about ethical challenges that filmmakers face can contribute new information to the pool of academic knowledge about documentary genre. It is arguable whether an ethical code for documentary filmmakers is necessary because it might not have the desirable consequences. There are many types of documentaries; and if documentaries are op-eds, as Kauffman said, then similar to opinion writers, documentarians have more creative freedom when dealing with ethical issues.

Documentary filmmaking doesn't have an organizational structure similar to what journalism has. Journalists have incentives for acting ethically because failure to do so might result in loosing a job and damaging a reputation. Independent documentarians are generally not dependent on any specific organization, so it is unclear who would make sure that ethical codes or guidelines are respected.

Currently there is not enough research on the topic and not much enthusiasm on the filmmakers' side about a possible ethical code. Many filmmakers believe they are skilled and experienced enough to make ethical decisions on their own, and there is no need for a universal code. Most filmmakers shared the idea of documentary ethics being 
based on virtue ethics theory - if a filmmaker is a thoughtful and ethical person, his films would be balanced and ethical too.

Based on the interviews done for this research, a few fundamental principles that filmmakers base their decisions on can be named. Their principles might serve as a base for a possible code of ethics. The first principle is commitment to truth telling and constructing an appealing and truthful story. The second principle mentioned by most filmmakers was not to harm, and not to expose the subjects because they are already vulnerable. The third principle is not manipulating the footage too much. All of the principles, however, are vague and can be interpreted in various ways. An ultimate question is how much manipulation is too much, and what truthful exactly means.

SPJ code of ethics is also criticized for vagueness (Singer, 2006); however, vagueness is generally unavoidable when dealing with ethics, and it shouldn't prevent both scholars and filmmakers from exploring this field.

\section{Limitations}

The main limitation of this research is that filmmakers' relationships with subjects and decision-making process are very personal. Filmmakers approach ethically challenging issues on a case-by-case basis, and though there are many similarities in the way documentarians deal with ethical challenges, it is hard to say how common the shared views are. Interviewing six people might not be enough to make solid conclusions.

Another limitation is the fact that all filmmakers were American, so when talking about their work and comparing documentary to journalism they all most likely had an American model of journalism in mind. Therefore, the findings might have been different if the interviews were conducted with filmmakers from different countries. The fact that 
all filmmakers interviewed were men is also somewhat limiting, and interviewing several women filmmakers would add diversity to this research project.

Documentary filmmaking is the field, which is hard to categorize as most filmmakers experiment with genres, topics and subjects. For research purposes it might have been useful to analyze documentaries dedicated to a similar issue. However, even though filmmakers acknowledged that they use different approaches to depending on the subjects and the issues covered in the film, the basics for their ethical decisions didn't change much. It is grounded on filmmakers' experience and personalities.

Semi-structured interview method allowed us to explore filmmakers' thoughts about decision-making process in depth, which is important in context of this research. Ethics is a complex issue, and filmmakers' elaborate responses to the questions helped detect patterns and study them in context. In future it might be beneficial to incorporate several methods such as content analysis of documentary films and ethnographic observation of filmmakers' working process. However, the latter can be challenging as filmmaking process usually takes a long time, and the presence of a researcher might complicate filmmakers' work.

There hasn't been much research done on ethics of documentary filmmaking, it was studied mostly from the arts perspective before, filmmaker being the creator of an artistic piece (Grierson, 1933; Renov, 1993). Recently, with technology development and growing public interest in documentary there have been attempts to explore the journalistic side of documentary. This research can be used to continue exploring common patterns between documentary and journalism, and what it means for the industry and its practitioners. 
To understand the process and make conclusions it is important to learn what people in the industry think about documentary genre, and how they deal with controversial issues. If any ethical guideline is to be created for documentary filmmakers, it should be created by joint efforts of scholars and filmmakers, and it should be based on the ideas and principles that filmmakers share.

\section{Contribution and future research}

A universal approach to ethical issues will very likely never be found, but the conversation about ethical decision-making as well as acknowledging gatekeeping forces facilitate honesty and transparency, which are crucial for the ethics discourse. Further research of other types of documentaries (advocacy films, participatory documentaries, films made specifically for a media outlet) can provide more information about decisionmaking process and gatekeeping forces.

This research has proven that ethical challenges and relationships with subjects are the topics that filmmakers think about; and all documentarians interviewed for this research admitted to being concerned about ethics and making ethical films, though each of them had his own understanding of ethics in documentary.

Some of the potential topics for further research may include gatekeeping roles of media organizations which broadcast documentaries (PBS, Al Jazeera, HBO); gatekeeping roles of film festivals (if there are specific characteristics that help films be picked by festivals); gatekeeping roles of sponsors and funders (if they have any expectations even though they are sponsoring independent documentary films).

It would also be interesting to select documentaries belonging to different categories (Nichols, 2006) and then to analyze the responses of filmmakers based on the 
type of a documentary they made.

It would also be interesting select documentaries belonging to different categories (Nichols, 2006) and analyze the responses of filmmakers based on the type of a documentary they made.

Another approach to research can be studying the subjects' opinions - how they feel being filmed, what expectations, if any, they have, what their motivations for participating are. This approach can provide more material for exploration of subjects' gatekeeping role.

The audience's perception of documentary as a genre hasn't really been explored before. It would be quite complicated to conduct such research, because documentary audience is fragmented, and many documentary films are hard to access - they are shown at film festivals, and then is takes from a few months to a few years before films become available on DVD or online.

However, research about the audience can contribute valuable information to the pool of knowledge and help scholars and filmmakers explore some of the key issues including when there is too much manipulation and how balanced and truthful the stories in the films are. Together with filmmakers' and subjects' perspective it might create an interesting pool of information, which would help explain the mechanisms of documentary filmmaking from different sides and angles. 


\section{REFERENCES}

Aufderheide, P. (2010). Perceived ethical conflicts in US documentary filmmaking: a field report. New Review of Film \& Television Studies; Vol. 10 Issue 3, p362-386, $25 \mathrm{p}$.

Aufderheide, P. (1998). The Camera as Conscience: How Social Issues Inspire Moving Documentaries. The Chronicle of Higher Education. http://chronicle.com/article/The-Camera-as-Conscience-H/2678/.

Baker, S.E. \& Edwards R. (2012). How many qualitative interviews is enough? National Centre for Research Methods, Southampton.

Barnouw, E. (1993). Documentary: A history of the non-fiction film. New York: Oxford UP.

Boyce, C. \& Neale, P. (2006). Conducting In-depth interviews: A Guide for Designing and Conducting In-depth Interviews for Evaluation Input.

http://www.pathfind.org/site/DocServer/m_e_tool_series_indepth_interviews.pdf? docID $=6301$

Bruns, A. (2011). Gatekeeping, gatewatching, real-time feedback: new challenges for journalism. Brazilian Journalism Research. http://eprints.qut.edu.au/47628/1/3551350-1-PB.pdf

Cassidy, W.P. (2006). Gatekeeping similar for online, print journalists. Newspaper research Journal. http://jclass.umd.edu/classes/jour698m/cassidy.pdf

Christians, D.G., \& Carey, J.W. (1981). The logic and aims of qualitative research. In G. H. Stempel III \& B. H. Westley (Eds.), Research methods in mass communication, 354-374.

Corbin, J. \& Strauss, A. (1990). Grounded theory research: procedures, canons, and evaluative criteria. Qualitative Sociology, 13(1), 3-21.

Craft, S., \& Davis, C. N. (2013). Principles of American journalism: An introduction. New York: Routledge.

Davis, M. (2010). Why journalism is a profession. Journalism Ethics: A Philosophical Approach. Oxford University Press 
Glasser, T.L. \& Ettema, J.S. (2008) Ethics and Eloquence in Journalism: An Approach to Press Accountability. Online. https://comm.stanford.edu/wpcontent/uploads/2013/01/glasser-ethics.pdf

Grierson, John (1996). 'First Principles of Documentary', in Kevin Macdonald \& Mark Cousins (eds.) Imagining Reality: The Faber Book of Documentary. London: Faber and Faber.

Harper, D. (2002). Talking about pictures: a case for photo elicitation. Visual Studies, $17(1)$.

Herzog, W. (2010). On the absolute, the sublime, and ecstatic truth. http://www.wernerherzog.com/52.html

Kovach, B. \& Rosenstiel, T. (2007). The elements of journalism: What newspeople should know and the public should expect. New York: Three Rivers Press.

Krantz, D.L. (1995). Sustaining vs. resolving the quantitative-qualitative debate. Evaluation and Program Planning, 18(1), 89-96.

Krawitz, J. (2010). Treading Softly: Ethics and Documentary Production Knowledge Quest, vol. 38(4) pp. 48-51.

LaMarre H.L., Landreville K.D. (2009. )When is Fiction as Good as Fact? Comparing the Influence of Documentary and Historical Reenactment Films on Engagement, Affect, Issue Interest, and Learning; Mass Communication and Society, 12(4).

Lambeth, E.B. (1986). Committed journalism: An ethic for the profession. Indiana University Press.

Levinas, E. (1998). Entre-Nous: On-thinking-of-the-other (M. B. Smith \& B. Harshav, Trans.). New York, NY: Columbia University Press.

Maccarone, E. (2010). Ethical Responsibilities to Subjects and Documentary Filmmaking. Journal of Mass Media Ethics: Exploring Questions of Media Morality, 25(3), 192-206.

Nash, K. (2011). Documentary-for-the-Other: Relationships, Ethics and (Observational) Documentary, University of Tasmania, Australia.

Nichols, B. (1992). Representing reality. Indiana University Press.

Nichols, B. (2010). Introduction to Documentary, Second Edition. Indiana University Press.

Nichols, B. (2006). What to Do About Documentary Distortion? Toward a Code of Ethics; http://www.documentary.org/content/what-do-about-documentarydistortion-toward-code-ethics-0 
Nolley, K. (2005). Fahrenheit 9/11: Documentary, Truth-telling, and Politics. Film \& History: An Interdisciplinary Journal of Film and Television Studies, 35(2).

Patterson, P., \& Wilkins, L. (2008). Media Ethics: Issues and cases ( $6^{\text {th }}$ ed.). Boston: McGraw-Hill.

Plaisance, P.L. (2008). Media Ethics: Key Principles for Responsible Practice.

Pryluck, C. (1976). Ultimately we are all outsiders: The ethics of documentary filming. In A. Rosenthal (Ed.), New challenges for documentary (pp. 255-268). Berkeley: University of California Press.

Renov, M. (1993). Introduction: The truth about non-fiction. In M. Renov (Ed.), Theorizing documentary. New York: Routledge.

Renov, M. (2004). Subject of Documentary. University Of Minnesota Press.

Rhoads, K. (2004) Propaganda Tactics and Fahrenheit 9/11 http://www.workingpsychology.com/download_folder/Propaganda_And_Fahrenh eit.pdf

Sanders, W. (2010). Documentary Filmmaking and Ethics: Concepts, Responsibilities, and the Need for Empirical Research; Mass Communication and Society, 13(5), 528-553.

Schramm, W. (1960). Mass communications. Urbana: University of Illinois Press.

Scott, B. (2005) A Contemporary History of Digital Journalism. Television New Media; 6.

Shoemaker, P. J., Eichholz, M., Kim, E., \& Wrigley, B. (2001). Individual and routine forces in gatekeeping. Journalism \& Mass Communication Quarterly, 78(2), 233246.

Shoemaker, P.J. \& Vos, T.P. (2009). Gatekeeping theory. New York: Routledge.

Siebert, F.S., Peterson, T. \& Schramm, W. (1963). Four Theories of the Press: The Authoritarian, Libertarian, Social Responsibility and Soviet Communist Concepts of What the Press Should Be and Do. University of Illinois Press.

Singer, J.B. (2006) The Socially Responsible Existentialist. Journalism Studies.

Singer, J.B. (2010) Norms and the network: Journalistic ethics in a shared media space. Journalism Ethics: A Philosophical Approach. Oxford University Press.

Small, M.L. (2009). How many cases do I need? On science and the logic of case selection in field-based research. Ethnography, 10(1), 5-38.

Tuchman, G. (1978). Making news. New York: Free Press. 
Velez A.M. (2008). Evaluating Research Methods: Assumptions, Strengths, and Weaknesses of Three Educational Research Paradigms. Davenport University. 